\title{
Study of physiologically active components in different parts of fruiting bodies of varieties of Agaricus bisporus (white mushroom)
}

\author{
Bożena Muszyńska ${ }^{1} \cdot$ Joanna Piotrowska $^{2} \cdot$ Agata Krakowska $^{2} \cdot$ Anna Gruba $^{2} \cdot$ Katarzyna Kała $^{1}$. \\ Katarzyna Sułkowska-Ziaja ${ }^{1} \cdot$ Agata Kryczyk $^{2} \cdot$ Włodzimierz Opoka $^{2}$
}

Received: 2 March 2017 / Revised: 24 April 2017 / Accepted: 13 May 2017 / Published online: 27 May 2017

(c) The Author(s) 2017. This article is an open access publication

\begin{abstract}
The study involved the fruiting bodies of white, brown, and portobello varieties of Agaricus bisporus. The content of bioelements and organic compounds was determined in the prepared samples of different varieties and different parts (cap peel, cap devoid of peel, and stipes) of mushrooms. We determined which of the A. bisporus varieties is characterized by higher nutritional value. Because consumers often peel the outer part of the mycelium that forms the fruiting body (cap peel), we therefore established the justification of such action by examining the content of bioelements and selected organic compounds in different parts of the fruiting body, and thus to show whether removal of cap peel is justified from the perspective of the content of health-promoting mineral elements. The content of metals was determined using atomic absorption and emission spectroscopy. Organic compounds were determined using reversed-phase high-performance liquid chromatography. Chemometric tools were used to facilitate the analysis and interpretation of the data obtained in the experiment. The study demonstrated that the brown varieties of $A$. bisporus are the richest in the examined substances and that the largest quantity of such content is accumulated in the cap peel.
\end{abstract}

Keywords Agaricus bisporus · Bioaccumulation ·

Bioelements · Indole compounds · Phenolic compounds ·

Atomic absorption spectroscopy

Bożena Muszyńska

muchon@poczta.fm

1 Department of Pharmaceutical Botany, Faculty of Pharmacy, Jagiellonian University Medical College, Kraków, Poland

2 Department of Inorganic and Analytical Chemistry, Faculty of Pharmacy, Jagiellonian University Medical College, Kraków, Poland

\section{Introduction}

Agaricus bisporus (J.E. Lange) Imbach (white mushroom) from Agaricaceae family is cultivated in at least 70 countries around the world. The world production of white mushroom in the early 1990s was 1.5 million tons [1]. The first information on the commercial cultivation of A. bisporus was obtained by the French botanist Joseph Pitton de Tournefort in 1707 [2]. Another French farmer Olivier de Serres observed that the transplantation of the mushroom mycelium on a new substrate leads to an increased number of fruiting bodies. This type of cultivation was performed by transferring the mycelium on a substrate containing a mixture of clay and manure. However, mushrooms obtained by this way of cultivation were often infected and did not result in good development of fruiting bodies. Pure mycelial cultures of A. bisporus were first cultivated in the Pasteur Institute of Paris on horse manure in 1893. Fruiting bodies obtained originally were brown, but white fruiting bodies were obtained in 1926 in Pennsylvania, and they gained much more popularity among the consumers. Because this species cultivation has its origin in Paris, its French common name is champignon de Paris [1, 2]. The most important features of $A$. bisporus are its dietary and healing properties resulting from the rich composition of metabolites and biologically active elements. It is a rich source of dietary fiber (chitin) and contains exogenous and endogenous amino acids, digestible protein, compounds with significant antioxidant activity (sterols, phenolic, and indole compounds), vitamins (especially vitamin D), and bioelements (e.g., selenium, zinc) [3-9]. The antioxidant activity of $A$. bisporus is also related to the presence of histidine derivative, ergothioneine [10]. Apart from its antioxidant properties, ergothioneine also exhibits antimutagenic, 
chemoprotective, and radioprotective activities; therefore, this substance is highly valued in medicine [11]. Tyrosinase extracted from white mushroom shows a high degree of similarity to the one observed in human body. Thus, this species is a valuable and concurrently inexpensive source of tyrosinase $[5,12,13]$. The studies conducted on the enzyme isolated from A. bisporus showed that it exhibits a protective effect on the human lymphoma cell lines, protecting them from the negative effects of damaging agents such as dihydrogen peroxide [14]. In addition, gene-protecting activity of this species was studied, which was a result of the presence of tyrosinase. Such protective effect may be related to the pathway of transformation of tyrosine into L-DOPA (L-3,4-dihydroxyphenylalanine), and further conversion into dopaquinone metabolite [14-16].

The fruiting bodies of this species also contain lovastatin, a compound with an anti-atherosclerosis activity [10, 17]. Thus, A. bisporus is a valuable foodstuff, meeting the standards for food with proven medicinal and dietary properties [18].

The aim of this study was to determine which of the A. bisporus varieties (white, brown, and portobello) has a higher nutritional and health-promoting value. The content of physiologically active elements such as $\mathrm{Na}, \mathrm{Mg}, \mathrm{Zn}, \mathrm{Cu}$, and $\mathrm{Fe}$, as well as indole and phenolic compounds, was determined in three varieties of the edible A. bisporus species: white, brown, and portobello. It was also determined in cap peel, cap devoid of peel, and stipe of these mushrooms' fruiting bodies. Because consumers often remove the outer part of the mycelium that forms the fruiting body, called cap peel, the aim of the study was to determine the plausibility of such action by examining the content of analyzed elements and organic compounds in particular parts of the fruiting body, and thus to show whether removal of cap peel could be justified from the perspective of content of health-promoting mineral elements.

The content of $\mathrm{Zn}, \mathrm{Cu}, \mathrm{Fe}$, and $\mathrm{Mg}$ was determined using atomic absorption spectrometry (AAS), whereas the content of $\mathrm{Na}$ was determined using atomic emission spectrometry (AES). The content of indole and phenolic compounds was determined using reversed-phase high-performance liquid chromatography (RP-HPLC).

\section{Materials and methods}

\section{Mushroom samples}

The study involved the fruiting bodies of selected edible fungi, A. bisporus (J.E. Lange) Imbach (white button mushroom) of commercial origin among white, brown, and portobello varieties. Taxonomic identification was made based on the key (http://www.mycokey.com) and publications of Knudsen and Vesterholt [19] by Muszyńska, and representative samples of the material used for the study were deposited at the Department of Pharmaceutical Botany, Jagiellonian University Medical College in Kraków, Poland.

\section{Reagents}

Nitric acid concentrated Suprapur ${ }^{\circledR}$, potassium nitrate Suprapur $^{\circledR} 30 \%$, and dihydrogen peroxide Suprapur ${ }^{\circledR}$ were purchased from Merck (Darmstadt, Germany); Zn(II) standard was purchased from OUM-7 Łódź, Poland. Standards of $\mathrm{Na}^{+}, \mathrm{Mg}^{2+}, \mathrm{Zn}^{2+}, \mathrm{Cu}^{2+}$, and $\mathrm{Fe}^{3+}$ ions in concentration $1 \mathrm{~g} / \mathrm{L}$; quadruple-distilled water with a conductivity of less than $1 \mu \mathrm{S} / \mathrm{cm}$ was obtained using an S2-97A2 distillation apparatus (Chemland, Stargard Szczecin, Poland). Standards of indole compounds such as L-tryptophan, 5-hydroxy-L-tryptophan, serotonin, melatonin, tryptamine, and 5-methyl-tryptamine were purchased from Sigma-Aldrich (St. Louis, MO, USA); all these were of HPLC grade. Phenolic compounds standards of HPLC grade: $p$-coumaric, ferulic, $p$-hydroxybenzoic, vanillic, and 3,4-dihydrophenylacetate acid were from Fluka (Chemie AG) and those of caffeic, chlorogenic, cinnamic, $o$-coumaric, protocatechuic, sinapic, gallic, and syringic acids and rutin were from Sigma-Aldrich (St. Louis, MO, USA). Methanol, ammonium acetate, acetic acid, and petroleum ether purchased from Merck (Darmstadt, Germany) were also of HPLC grade.

\section{Sample preparation}

Particular varieties of A. bisporus were purified using a plastic knife and divided into parts (cap peel, cap, and stipe), and then the mushroom material was lyophilized (temperature $-40{ }^{\circ} \mathrm{C}$, Freezone 4.5 lyophilizer; Labconco, Kansas City). The lyophilized parts were ground in an agate mortar and weighed in amount of $0.2 \mathrm{~g}$ with an accuracy of $0.1 \mathrm{mg}$, and then "wet" mineralized (temperature: 295$300{ }^{\circ} \mathrm{C}$, pressure: $42-45$ bar, microwave power: $100 \%$, time: $30 \mathrm{~min}$ ) with the addition of dihydrogen peroxide $(3.5 \mathrm{~mL})$ and nitric acid solutions $(7 \mathrm{~mL})$. Colorless and clear solutions were obtained (microwave digestion system Magnum II; Ertec Poland, Wrocław, Poland). After the evaporation of solvents to the volume of $\sim 2 \mathrm{~mL}$ (MAG HP7 Z hob), the solutions were quantitatively transferred to volumetric flasks and filled with distilled water 4 times the volume of $25 \mathrm{~mL}$. Such prepared samples were examined for the content of individual bioelements using AAS and AES via iCE3000 (Thermo Scientific spectrophotometer, UK). 


\section{Determination of the content of bioelements}

The content of $\mathrm{Mg}, \mathrm{Fe}, \mathrm{Zn}$ and $\mathrm{Cu}$ in the fruiting bodies of $A$. bisporus was determined using AAS, whereas the content of $\mathrm{Na}$ was performed using AES. All analyses were performed in air-acetylene flame using three replicates with a measuring time of $2 \mathrm{~s}$, a sample suction time of $2 \mathrm{~s}$, and optimized spectrometer parameters such as acetylene flow, torch height, and gap width, and using analytical wavelengths appropriate for particular elements. The results were obtained from appropriate standard curves, whose parameters are presented in Table 1.

\section{RP-HPLC analysis of indole compounds}

The dry biomass ( $0.5 \mathrm{~g}$ of mushroom sample) was ground in a mortar and then subjected to extraction with petroleum ether to remove lipids [20, 21]. Defatted material was extracted in a glass percolator by methanol. The obtained extract was evaporated to dryness using an evaporator (Buchi, Germany) under a pressure of $200 \mathrm{mBa}$ at $40^{\circ} \mathrm{C}$. The concentrated analyte was dissolved in methanol transferred through a Whatman No. 3 filter paper. The extracts were quantitatively dissolved in $1.5 \mathrm{~mL}$ of solvent system (methanol:water:ammonium acetate at 15:14:1 v/v/v) and subjected to separation by RP-HPLC using the Hitachi HPLC (Merck, Tokyo, Japan) equipped with a pump type L-7100, the Purospher ${ }^{\circledR}$ RP-18 $(4 \times 200 \mathrm{~mm}, 5 \mu \mathrm{m})$ column thermostated at $25{ }^{\circ} \mathrm{C}$, and an ultraviolet (UV) detector operated at $\lambda=280 \mathrm{~nm}$. The liquid phase used was a mixture of methanol, water, and ammonium acetate $(15: 14: 1 \mathrm{v} / \mathrm{v} / \mathrm{v})$ at the flow rate of $1 \mathrm{~mL} / \mathrm{min}$. The quantitative analysis of indole compounds was performed using a calibration curve with the assumption of the linear size of the area under the peak and the concentration of the reference standard. The results were expressed in $\mathrm{mg} / 100 \mathrm{~g}$ of dry weight (d.w.). The chromatogram for the indole compounds obtained after analyzing the sample derived from methanolic extracts of A. bisporus is presented in Fig. 1 .

\section{Analysis of phenolic compounds}

The obtained extracts, similar to indole compounds, were analyzed for the contents of phenolic compounds by the RP-HPLC method. These analyses were carried out according to the procedure developed by Ellnain-Wojtaszek and Zgórka [22] with some modifications. RP-HPLC analyses were conducted using an HPLC VWR Hitachi-Merck apparatus (Darmstadt, Germany): autosampler L-2200, pump L-2130, Li Chrospher RP-18e column $(250 \times 4 \mathrm{~mm}$,

Table 1 Parameters of calibration curves for the examined bioelements in the fruiting bodies of A. bisporus

\begin{tabular}{|c|c|c|c|}
\hline & Concentration range $(\mathrm{mg} / \mathrm{L})$ & Calibration curve equation & Correlation coefficient $(r)$ \\
\hline \multicolumn{4}{|l|}{ Element } \\
\hline $\mathrm{Na}$ & $0.0-1.0$ & $y=-10.5403 x^{2}+107.654 x+1.8434$ & 0.9994 \\
\hline $\mathrm{Mg}$ & $0.0-0.3$ & $y=0.87178 x+0.0052$ & 0.9977 \\
\hline $\mathrm{Fe}$ & $0.0-5.0$ & $y=0.06039 x+0.0023$ & 0.9995 \\
\hline $\mathrm{Zn}$ & $0.0-1.0$ & $y=0.35158 x-0.0042$ & 0.9990 \\
\hline $\mathrm{Cu}$ & $0.0-0.5$ & $y=0.15953 x-0.0031$ & 0.9958 \\
\hline \multicolumn{4}{|l|}{ Indole compounds } \\
\hline L-Tryptophan & $0.05-0.3$ & $y=22330842 x+159577.1$ & 0.9988 \\
\hline 5-Hydroxy-L-tryptophan & $0.05-0.3$ & $y=17412286 x-220312$ & 0.9988 \\
\hline Serotonin & $0.05-0.3$ & $y=17468319 x+313434.9$ & 0.9986 \\
\hline Tryptamine & $0.05-0.3$ & $y=46179459 x-1461620$ & 0.9886 \\
\hline 5-Methyl-tryptamine & $0.05-0.3$ & $y=22657852 x-184577$ & 0.9994 \\
\hline Melatonin & $0.05-0.3$ & $y=36191138 x-188763$ & 0.9988 \\
\hline \multicolumn{4}{|l|}{ Phenolic compounds } \\
\hline Gallic acid & $0.05-0.31$ & $y=76259415.3 x-378551.4348$ & 0.9988 \\
\hline Protocatechuic acid & $0.05-0.01$ & $y=133755996.5 x+159880.8261$ & 0.9991 \\
\hline$p$-Hydroxy-benzoic acid & $0.05-0.31$ & $y=238764516.2 x+496475.6087$ & 0.9941 \\
\hline Syringic acid & $0.05-0.31$ & $y=63368421.22 x-53562.73913$ & 0.9988 \\
\hline Cinnamic acid & $0.05-0.31$ & $y=153676175.8 x-526651.25$ & 0.9997 \\
\hline Rutin & $0.05-0.31$ & $y=60000000 x+66560$ & 0.9998 \\
\hline
\end{tabular}

The values of LOD for bioelements ranged from 0.1 to $1.5 \mu \mathrm{g} / \mathrm{L}$, for indole compounds from 1.48 to $8.31 \mathrm{mg} / \mathrm{mL}$ and for phenolic compounds from 0.01 to $0.13 \mathrm{mg} / \mathrm{mL}$

$y$ absorbance or emission, $x$ concentration $(\mathrm{mg} / \mathrm{L}), r$ correlation coefficient 


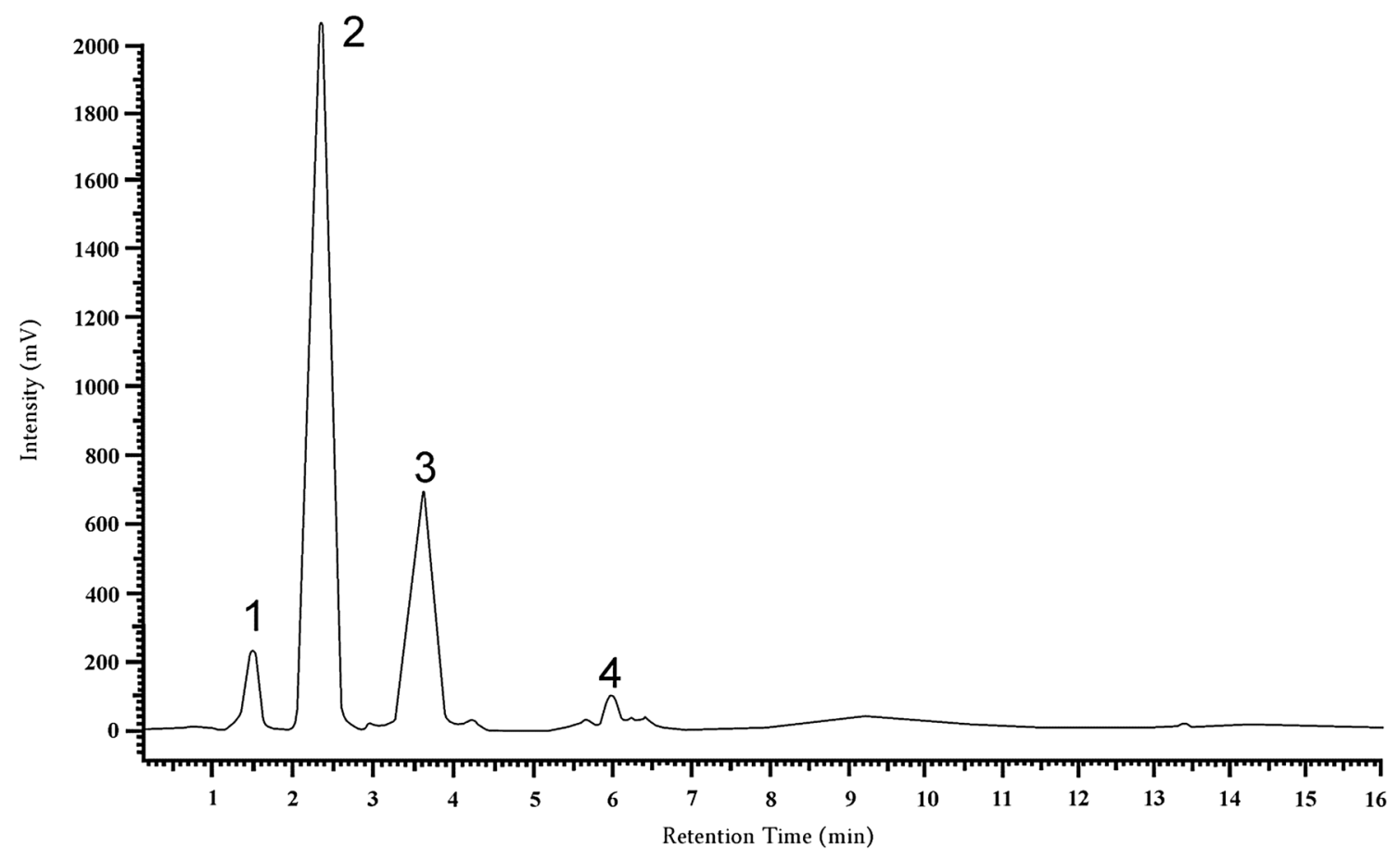

Fig. 1 RP-HPLC chromatogram for indole compounds determined in methanolic extracts from outer part of the cap (peel) of the fruiting bodies of brown variety $A$. bisporus: 1 serotonin; 2 5-hydroxytryptophan; 3 L-tryptophan; 4 5-methyl-tryptamine

$5 \mu \mathrm{m})$ thermostated at $25^{\circ} \mathrm{C}, \mathrm{L}-2350$ column oven, and L-2455 diode array detector at a UV range of 200-400 nm. The mobile phase consisted of solvent A (methanol:0.5\% acetic acid 1:4 [v/v]) and solvent $B$ (methanol). The gradient was as follows: $100 \% \mathrm{~B}$ for $0-20 \mathrm{~min} ; 100-80 \% \mathrm{~B}$ for $20-35 \mathrm{~min}$; $80-60 \%$ B for $35-55 \mathrm{~min} ; 60-0 \%$ B for 55-70 min; 0\% B for 70-75 min; 0-100\% B for 75-80 min; $100 \%$ B for $80-90 \mathrm{~min}$ at a flow rate $1 \mathrm{ml} / \mathrm{min}, \lambda=254 \mathrm{~nm}$ (phenolic acids). The comparison of UV spectra and retention times with standard compounds enabled the identification of phenolic compounds present in the samples. The quantitative analysis of free phenolic compounds was performed using a calibration curve with the assumption of the linear size of the area under the peak and the concentration of the reference standard. The results were expressed in $\mathrm{mg} / 100 \mathrm{~g}$ of d.w. The chromatogram for phenolic compounds obtained after analyzing the sample derived from methanolic extracts of A. bisporus is presented in Fig. 2.

\section{Statistical analysis}

Statistical analysis of the data was performed using oneway analysis of variance with Tukey-Kramer post hoc multiple comparisons. A $p$ value of $<0.05$ was accepted as the level of statistical significance. Chemometric tools were used to facilitate the analysis and interpretation of the data obtained in the experiment; these included the two main methods: cluster analysis (CA) and principal component analysis (PCA). Calculations were performed using GraphPad InStat software (USA), and Statgraphics Centurion XVII. Statistical significance was established at $p<0.05$.

\section{Results and discussion}

\section{Bioelements}

Three varieties of $A$. bisporus (white, brown, and portobello) were used in the experiment, taking into account particular parts of the fruiting bodies, which were examined using AAS and AES for the content of chemical elements $\mathrm{Na}, \mathrm{Mg}, \mathrm{Cu}, \mathrm{Fe}$, and $\mathrm{Zn}(\mathrm{mg} / 100 \mathrm{~g}$ d.w.). The average results (three samples, three replicates) with the values of calculated standard deviations are presented in Table 2 .

The AES analysis showed that the content of sodium in the fruiting bodies of varieties of A. bisporus and their parts differed considerably. The amount of sodium determined from the parts of the fruiting bodies of the white variety of A. bisporus $(321.1 \mathrm{mg} / 100 \mathrm{~g}$ d.w. for cap peel, $373.2 \mathrm{mg} / 100 \mathrm{~g}$ d.w. for cap, and $410.6 \mathrm{mg} / 100 \mathrm{~g}$ d.w. for stipe) differs from the content previously found in the whole fruiting bodies of the same variety of button mushroom $(76.0-86.0 \mathrm{mg} / 100 \mathrm{~g}$ d.w.) $[23,24]$. The highest amount of sodium was found in the peel of the portobello 


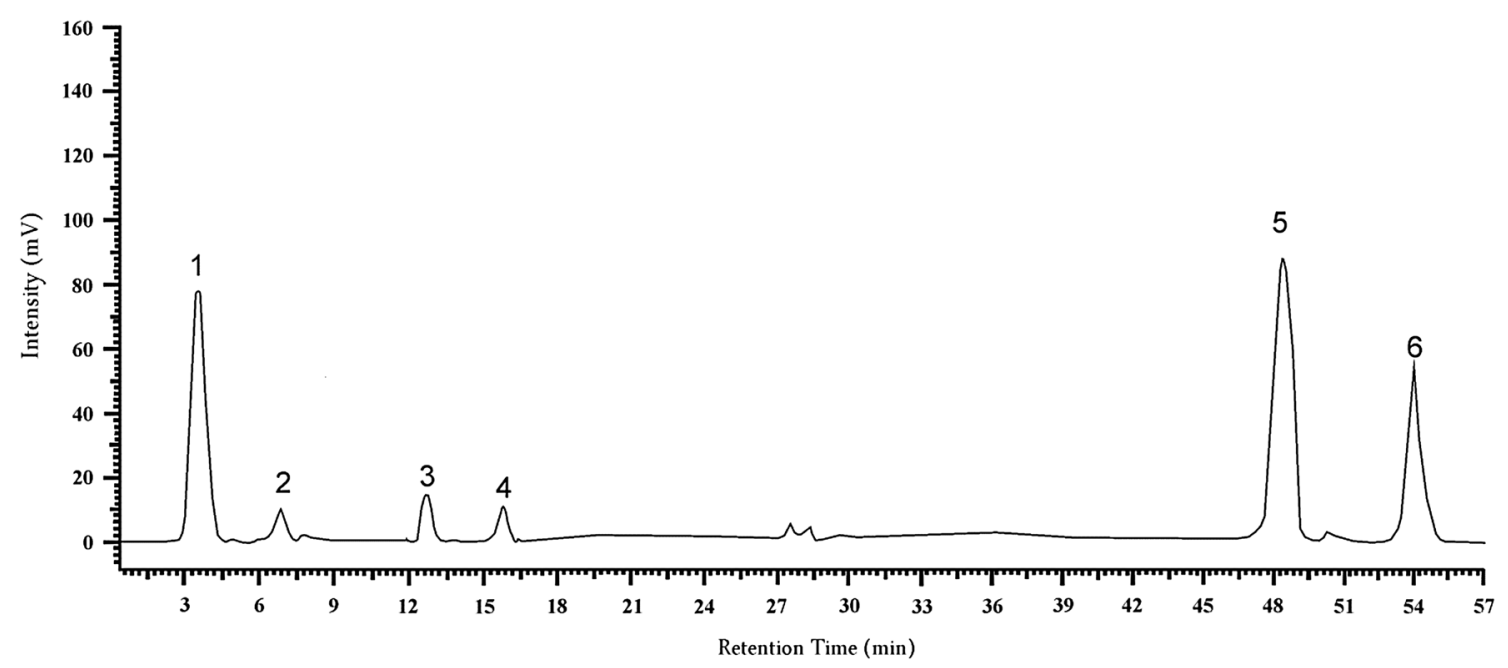

Fig. 2 RP-HPLC chromatogram for phenolic compounds determined in methanolic extracts from outer part of the cap (peel) of the fruiting bodies of brown variety A. bisporus: 1 gallic acid; 2 protocatechuic acid; 3 p-hydroxybenzoic acid; 4 syringic acid; 5 rutin; 6 cinnamic acid

variety of A. bisporus (412.3 mg/100 g d.w.). The average amount of sodium was the highest in the white variety $(368.3 \mathrm{mg} / 100 \mathrm{~g} \mathrm{d.w.})$, lower in the brown variety (306.6 mg/100 g d.w.), and the lowest in the portobello variety (277.3 mg/100 g d.w.) (Fig. 3).

The content of magnesium determined in the fruiting bodies of the white variety of A. bisporus (cap peel: $112.8 \mathrm{mg} / 100 \mathrm{~g}$ d.w.; cap: $112.4 \mathrm{mg} / 100 \mathrm{~g}$ d.w.; stipe: $112.0 \mathrm{mg} / 100 \mathrm{~g} \mathrm{d.w.})$ did not differ from the results previously obtained from the whole fruiting bodies of the same variety, where the content of magnesium was in the range of $91.0-227.5 \mathrm{mg} / 100 \mathrm{~g}$ d.w. [23, 25, 26]. The concentrations of magnesium in other varieties of button mushroom-brown and portobello that reached $59.8-123.2 \mathrm{mg} / 100 \mathrm{~g}$ d.w.- - showed no deviations from the previously presented content. The highest magnesium content was observed in the cap peel of brown variety $(123.2 \mathrm{mg} / 100 \mathrm{~g}$ d.w.). Similar to sodium, the magnesium content in the stipes and caps of the different varieties of $A$. bisporus was the highest in the white variety. The highest average content in the fruiting bodies in the white variety of A. bisporus (112.5 mg/100 g d.w.), lower in the brown variety of $A$. bisporus (109.9 $\mathrm{mg} / 100 \mathrm{~g}$ d.w.), and the lowest in the portobello variety of A. bisporus $(87.2 \mathrm{mg} / 100 \mathrm{~g}$ d.w.) (Fig. 3).

The content of iron in the fruiting bodies of all examined varieties of $A$. bisporus was in the range of 1.8 $10.2 \mathrm{mg} / 100 \mathrm{~g}$ d.w. and did not differ from that reported by other sources, that is, $1.4-16.2 \mathrm{mg} / 100 \mathrm{~g}$ d.w. $[25,26]$. The outer part of the cap mycelium of brown variety was characterized by the highest iron content of $10.2 \mathrm{mg} / 100 \mathrm{~g}$ d.w. The highest amount of iron was also found in the caps and stipes of the examined varieties $(3.6 \mathrm{mg} / 100 \mathrm{~g}$ d.w. and $4.0 \mathrm{mg} / 100 \mathrm{~g}$ d.w., respectively). The content of iron is the highest in the cap peels of A. bisporus (white variety: $6.4 \mathrm{mg} / 100 \mathrm{~g}$ d.w.; brown variety: $10.2 \mathrm{mg} / 100 \mathrm{~g}$ d.w.; portobello variety: $6.5 \mathrm{mg} / 100 \mathrm{~g}$ d.w.). The iron content was the lowest in the portobello variety $(3.6 \mathrm{mg} / 100 \mathrm{~g} \mathrm{~d}$.w.), slightly higher in the white variety $(3.9 \mathrm{mg} / 100 \mathrm{~g} \mathrm{~d}$.w.), and the highest in the brown variety $(5.9 \mathrm{mg} / 100 \mathrm{~g}$ d.w.) (Fig. 4).

The zinc content in particular parts of the examined varieties of A. bisporus is the highest in the brown variety both: $5.8 \mathrm{mg} / 100 \mathrm{~g}$ d.w. for stipes, $5.6 \mathrm{mg} / 100 \mathrm{~g}$ d.w. for caps, and $6.3 \mathrm{mg} / 100 \mathrm{~g}$ d.w for cap peels. The highest content of this element was found in the cap peels. Total zinc content in particular parts and varieties of button mushroom was in the range of 3.9-6.3 mg/100 g d.w. It is consistent with the zinc content presented in previous studies on the white variety of A. bisporus (5.5-11.3 mg/100 g d.w.) [26]. The average zinc content in the fruiting bodies of particular varieties of $A$. bisporus is as follows: white variety $-4.7 \mathrm{mg} / 100 \mathrm{~g}$ d.w., brown variety- $5.9 \mathrm{mg} / 100 \mathrm{~g}$ d.w., and portobello variety $-4.7 \mathrm{mg} / 100 \mathrm{~g}$ d.w. From this, it can be concluded that, as in case of iron, the brown variety is characterized by the highest zinc content in the fruiting bodies (Fig. 4).

The content of copper present in the fruiting bodies of particular parts and varieties of A. bisporus also differed and was within the range of $0.9-2.1 \mathrm{mg} / 100 \mathrm{~g}$ d.w.; it was slightly lower than that found in previous studies (2.1$5.2 \mathrm{mg} / 100 \mathrm{~g}$ d.w.) $[25,26]$. When comparing the copper content in the cap peels, caps, and stipes of different varieties of button mushroom, the highest content was found in the white variety $(2.1 / 100,1.9 \mathrm{mg} / 100,1.9 \mathrm{mg} / \mathrm{kg} \mathrm{d}$.w., respectively). The highest amount of this element (unlike in the case of iron and zinc) was found in the white 
Table 2 Bioelements and organic compounds content in various parts of three varieties of A. bisporus

\begin{tabular}{|c|c|c|c|c|c|c|c|c|}
\hline Bioelements & \multicolumn{2}{|l|}{$\mathrm{Na}$} & \multicolumn{2}{|l|}{$\mathrm{Mg}$} & $\mathrm{Fe}$ & \multicolumn{2}{|l|}{$\mathrm{Zn}$} & $\mathrm{Cu}$ \\
\hline \multicolumn{9}{|c|}{ Part of fruiting body $A$. bisporus white variety (mg/100 g dw) } \\
\hline Peel of cap & \multicolumn{2}{|c|}{$321.1 \pm 13.4^{\mathrm{a}}$} & \multicolumn{2}{|c|}{$112.8 \pm 1.2^{\mathrm{a}, \mathrm{b}}$} & $6.4 \pm 0.2^{\mathrm{a}, \mathrm{b}}$ & \multicolumn{2}{|l|}{$4.9 \pm 0.1^{\mathrm{a}, \mathrm{b}}$} & $2.1 \pm 0.1^{\mathrm{a}, \mathrm{b}}$ \\
\hline Cap & \multicolumn{2}{|c|}{$373.2 \pm 28.5^{\mathrm{a}}$} & \multicolumn{2}{|c|}{$112.4 \pm 1.6^{\mathrm{a}, \mathrm{b}}$} & $2.3 \pm 0.1^{\mathrm{a}, \mathrm{b}}$ & \multicolumn{2}{|l|}{$4.6 \pm 0.1^{\mathrm{a}, \mathrm{b}}$} & $1.9 \pm 0.1^{\mathrm{a}, \mathrm{b}}$ \\
\hline Stipe & \multicolumn{2}{|c|}{$410.6 \pm 14.6^{\mathrm{a}}$} & \multicolumn{2}{|c|}{$112.0 \pm 2.6^{\mathrm{a}, \mathrm{b}}$} & $2.9 \pm 0.1^{\mathrm{a}, \mathrm{b}}$ & \multicolumn{2}{|l|}{$4.5 \pm 0.4^{\mathrm{a}, \mathrm{b}}$} & $1.9 \pm 0.1^{\mathrm{a}, \mathrm{b}}$ \\
\hline \multicolumn{9}{|c|}{ A. bisporus brown variety $(\mathrm{mg} / 100 \mathrm{~g} \mathrm{dw})$} \\
\hline Peel of cap & \multicolumn{2}{|c|}{$369.8 \pm 25.2^{\mathrm{a}}$} & \multicolumn{2}{|c|}{$123.2 \pm 2.7^{\mathrm{a}, \mathrm{b}}$} & $10.2 \pm 0.4^{\mathrm{a}, \mathrm{b}}$ & \multicolumn{2}{|c|}{$6.3 \pm 0.01^{\mathrm{a}, \mathrm{b}}$} & $2.0 \pm 0.01^{\mathrm{a}, \mathrm{b}}$ \\
\hline Cap & \multicolumn{2}{|c|}{$325.6 \pm 25.1^{\mathrm{a}}$} & \multicolumn{2}{|c|}{$104.5 \pm 3.0^{\mathrm{a}, \mathrm{b}}$} & $3.6 \pm 0.1^{\mathrm{a}, \mathrm{b}}$ & \multicolumn{2}{|c|}{$5.6 \pm 0.1^{\mathrm{a}, \mathrm{b}}$} & $1.6 \pm 0.1^{\mathrm{a}, \mathrm{b}}$ \\
\hline Stipe & \multicolumn{2}{|c|}{$224.6 \pm 11.7^{\mathrm{a}}$} & \multicolumn{2}{|c|}{$102.1 \pm 3.7^{\mathrm{a}, \mathrm{b}}$} & $4.0 \pm 0.1^{\mathrm{a}, \mathrm{b}}$ & \multicolumn{2}{|l|}{$5.8 \pm 0.1^{\mathrm{a}, \mathrm{b}}$} & $1.6 \pm 0.1^{\mathrm{a}, \mathrm{b}}$ \\
\hline \multicolumn{9}{|c|}{ A. bisporus portobello variety $(\mathrm{mg} / 100 \mathrm{~g} \mathrm{dw})$} \\
\hline Peel of cap & \multicolumn{2}{|c|}{$412.5 \pm 3.6^{\mathrm{a}}$} & \multicolumn{2}{|c|}{$110.4 \pm 2.9^{\mathrm{a}, \mathrm{b}}$} & $6.5 \pm 0.3^{\mathrm{a}, \mathrm{b}}$ & \multicolumn{2}{|l|}{$5.3 \pm 0.1^{\mathrm{a}, \mathrm{b}}$} & $1.7 \pm 0.1^{\mathrm{a}, \mathrm{b}}$ \\
\hline Cap & $174.4 \pm$ & $10.6^{\mathrm{a}}$ & $91.4 \pm$ & $1.6^{\mathrm{a}, \mathrm{b}}$ & $2.3 \pm 0.1^{\mathrm{a}, \mathrm{b}}$ & $4.9 \pm 0.1^{\mathrm{a}, \mathrm{b}}$ & & $1.5 \pm 0.1^{\mathrm{a}, \mathrm{b}}$ \\
\hline Stipe & $245.1 \pm$ & $8.0^{\mathrm{a}}$ & $59.9 \pm$ & $1.3^{\mathrm{a}, \mathrm{b}}$ & $1.9 \pm 0.1^{\mathrm{a}, \mathrm{b}}$ & $3.9 \pm 0.01^{\mathrm{a}}$ & & $0.9 \pm 0.01^{\mathrm{a}, \mathrm{b}}$ \\
\hline Indole compounds & L-Tryptophan & 5-Hydroxy-L-try & ptophan & Serotonin & Tryptamine & 5-Methyl-tryptamine & Melatonin & Total content \\
\hline A. bisporus white $\mathrm{v}$ & riety $(\mathrm{mg} / 100 \mathrm{~g}$ & g dw) & & & & & & \\
\hline Peel of cap & $10.1 \pm 0.3^{\mathrm{a}}$ & $185.9 \pm 14.2 \mathrm{a}$ & & nd & nd & nd & nd & 196.0 \\
\hline Cap & $30.7 \pm 5.9^{\mathrm{a}}$ & $68.2 \pm 2.4^{\mathrm{a}}$ & & nd & nd & nd & nd & 98.9 \\
\hline Stipe & $10.5 \pm 1.6^{\mathrm{a}}$ & $118.6 \pm 2.3^{\mathrm{a}}$ & & nd & nd & nd & nd & 129.1 \\
\hline A. bisporus brown & ariety $(\mathrm{mg} / 100$ & $\mathrm{g} \mathrm{dw})$ & & & & & & \\
\hline Peel of cap & $50.2 \pm 2.5^{\mathrm{a}}$ & $158.2 \pm 6.2^{\mathrm{a}, \mathrm{b}}$ & & $11.0 \pm 2.3^{\mathrm{a}, \mathrm{b}}$ & & $5.4 \pm 0.4^{\mathrm{a}, \mathrm{b}}$ & nd & 224.8 \\
\hline Cap & $20.9 \pm 3.5^{\mathrm{a}}$ & $61.5 \pm 2.5^{\mathrm{a}, \mathrm{b}}$ & & nd & $3.6 \pm 0.1^{\mathrm{a}, \mathrm{b}}$ & nd & nd & 86.0 \\
\hline Stipe & $17.8 \pm 0.4^{\mathrm{a}}$ & $108.3 \pm 1.7^{\mathrm{a}, \mathrm{b}}$ & & $56.3 \pm 1.1^{\mathrm{a}, \mathrm{b}, \mathrm{c}}$ & $9.2 \pm 0.1^{\mathrm{a}, \mathrm{b}, \mathrm{c}}$ & nd & nd & 191.6 \\
\hline A. bisporus portobe & lo variety (mg/ & $100 \mathrm{~g} \mathrm{dw})$ & & & & & & \\
\hline Peel of cap & $29.8 \pm 2.5^{\mathrm{a}}$ & $174.3 \pm 0.5^{\mathrm{a}, \mathrm{b}}$ & & $20.5 \pm 0.5^{\mathrm{a}, \mathrm{b}, \mathrm{c}}$ & $15.0 \pm 1.0^{\mathrm{a}, \mathrm{b}, \mathrm{c}}$ & nd & nd & 239.6 \\
\hline Cap & $10.2 \pm 0.5^{\mathrm{a}}$ & nd & & nd & $3.2 \pm 0.1^{\mathrm{a}}$ & nd & nd & 13.4 \\
\hline Stipe & $16.8 \pm 2.3^{\mathrm{a}}$ & $191.9 \pm 2.6^{\mathrm{a}, \mathrm{b}}$ & & nd & nd & nd & $2.3 \pm 0.2^{\mathrm{a}, \mathrm{b}}$ & 211.0 \\
\hline $\begin{array}{l}\text { Phenolic com- } \\
\text { pound }\end{array}$ & Gallic acid & $\begin{array}{l}\text { Protocatechuic } \\
\text { acid }\end{array}$ & $\begin{array}{l}p \text {-Hydı } \\
\text { zoic ac }\end{array}$ & $\begin{array}{l}\text { oxy-ben- } \\
\text { id }\end{array}$ & yringic acid & Cinnamic acid & & Total content \\
\hline
\end{tabular}

Part of fruiting body A. bisporus white variety ( $\mathrm{mg} / 100 \mathrm{~g} \mathrm{dw})$

$\begin{array}{llllllll}\text { Peel of cap } & 9.2 \pm 0.06^{\mathrm{a}} & 0.7 \pm 0.03^{\mathrm{a}, \mathrm{b}} & 1.1 \pm 0.01^{\mathrm{a}, \mathrm{b}, \mathrm{c}} & 0.4 \pm 0.03^{\mathrm{a}, \mathrm{b}, \mathrm{c}} & 1.7 \pm 0.04^{\mathrm{a}, \mathrm{b}, \mathrm{c}, \mathrm{d}, \mathrm{e}} & 6.1 \pm 0.18^{\mathrm{a}, \mathrm{b}, \mathrm{c}, \mathrm{d}, \mathrm{e}} & 19.2 \\ \text { Cap } & 0.3 \pm 0.00^{\mathrm{a}} & 0.2 \pm 0.01^{\mathrm{a}, \mathrm{b}} & 0.3 \pm 0.00^{\mathrm{b}, \mathrm{c}} & 0.2 \pm 0.00^{\mathrm{a}, \mathrm{c}, \mathrm{d}} & 0.4 \pm 0.01^{\mathrm{a}, \mathrm{b}, \mathrm{c}, \mathrm{d}, \mathrm{e}} & 2.6 \pm 0.05^{\mathrm{a}, \mathrm{b}, \mathrm{c}, \mathrm{d}, \mathrm{e}} & 4.0 \\ \text { Stipe } & 0.5 \pm 0.01^{\mathrm{a}} & 0.6 \pm 0.00^{\mathrm{b}} & 0.4 \pm 0.01^{\mathrm{b}, \mathrm{c}} & 0.3 \pm 0.00^{\mathrm{a}, \mathrm{b}, \mathrm{d}} & 0.2 \pm 0.01^{\mathrm{a}, \mathrm{b}, \mathrm{c}} & 7.9 \pm 0.10^{\mathrm{a}, \mathrm{b}, \mathrm{c}, \mathrm{d}} & 9.9\end{array}$

A. bisporus brown variety $(\mathrm{mg} / 100 \mathrm{~g} \mathrm{dw})$

$\begin{array}{llllllll}\text { Peel of cap } & 8.0 \pm 0.09^{\mathrm{a}} & 0.9 \pm 0.01^{\mathrm{a}, \mathrm{b}} & 1.1 \pm 0.01^{\mathrm{a}, \mathrm{c}} & 0.8 \pm 0.00^{\mathrm{a}, \mathrm{d}} & 5.4 \pm 0.12^{\mathrm{a}, \mathrm{b}, \mathrm{c}, \mathrm{d}, \mathrm{e}} & 10.3 \pm 0.30^{\mathrm{a}, \mathrm{b}, \mathrm{c}, \mathrm{d}, \mathrm{e}} & 26.5 \\ \text { Cap } & 0.2 \pm 0.01^{\mathrm{a}} & 0.3 \pm 0.01^{\mathrm{b}} & 0.7 \pm 0.02^{\mathrm{a}, \mathrm{b}, \mathrm{c}} & 0.4 \pm 0.00^{\mathrm{a}, \mathrm{c}, \mathrm{d}} & 1.1 \pm 0.01^{\mathrm{a}, \mathrm{b}, \mathrm{c}, \mathrm{d}, \mathrm{e}} & 5.1 \pm 0.11^{\mathrm{a}, \mathrm{b}, \mathrm{c}, \mathrm{d}, \mathrm{e}} & 7.8 \\ \text { Stipe } & 0.1 \pm 0.00^{\mathrm{a}} & 0.5 \pm 0.01^{\mathrm{a}, \mathrm{b}} & 0.4 \pm 0.01^{\mathrm{a}, \mathrm{c}} & 0.2 \pm 0.00^{\mathrm{b}, \mathrm{c}, \mathrm{d}} & 0.1 \pm 0.00^{\mathrm{b}, \mathrm{c}, \mathrm{e}} & 6.0 \pm 0.09^{\mathrm{a}, \mathrm{b}, \mathrm{c}, \mathrm{d}, \mathrm{e}} & 7.3\end{array}$

A. bisporus portobello variety $(\mathrm{mg} / 100 \mathrm{~g} \mathrm{dw})$

$\begin{array}{llllllll}\text { Peel of cap } & 1.4 \pm 0.01^{\mathrm{a}} & 0.8 \pm 0.02^{\mathrm{a}, \mathrm{b}} & 2.0 \pm 0.03^{\mathrm{a}, \mathrm{b}, \mathrm{c}} & 0.7 \pm 0.00^{\mathrm{a}, \mathrm{c}, \mathrm{d}} & 0.2 \pm 0.08^{\mathrm{a}, \mathrm{b}, \mathrm{c}, \mathrm{d}, \mathrm{e}} & 11.1 \pm 0.17^{\mathrm{a}, \mathrm{b}, \mathrm{c}, \mathrm{d}, \mathrm{e}} & 16.2 \\ \text { Cap } & 0.2 \pm 0.00^{\mathrm{a}} & 0.2 \pm 0.09^{\mathrm{a}, \mathrm{b}} & 0.4 \pm 0.00^{\mathrm{a}, \mathrm{b}, \mathrm{c}} & 0.2 \pm 0.00^{\mathrm{b}, \mathrm{c}, \mathrm{d}} & 0.3 \pm 0.02^{\mathrm{b}, \mathrm{e}} & 3.4 \pm 0.07^{\mathrm{a}, \mathrm{b}, \mathrm{c}, \mathrm{d}, \mathrm{e}} & 4.7 \\ \text { Stipe } & 0.6 \pm 0.00^{\mathrm{a}} & 0.6 \pm 0.01^{\mathrm{b}} & 0.9 \pm 0.00^{\mathrm{a}, \mathrm{b}, \mathrm{c}} & 0.4 \pm 0.00^{\mathrm{a}, \mathrm{b}, \mathrm{c}, \mathrm{d}} & 0.2 \pm 0.00^{\mathrm{a}, \mathrm{b}, \mathrm{c}, \mathrm{d}, \mathrm{e}} & 5.6 \pm 0.08^{\mathrm{a}, \mathrm{b}, \mathrm{c}, \mathrm{d}, \mathrm{e}} & 8.3\end{array}$

Data are presented as the mean $\pm \mathrm{SD}$ (standard deviation); $n=3$ repetitions. Tukey-Kramer test was used to reveal the differences between paired groups of phenolic compounds in rows, the same letters (a, b, c, d, e) are marked for the content whose differences are statistically significant (for $p$ values <0.05) (GraphPad InStat)

$n d$ not detected

variety of A. bisporus ( $2.0 \mathrm{mg} / 100 \mathrm{~g}$ d.w.), slightly lower in the brown variety $(1.7 \mathrm{mg} / 100 \mathrm{~g} \mathrm{~d} . \mathrm{w}$., and the lowest in the portobello variety (1.4 mg/100 g d.w.) (Fig. 4).
Analysis of zinc, magnesium, and iron content showed their highest amounts in cap peels of brown variety. Moreover, it was shown, comparing the content of bioelements 


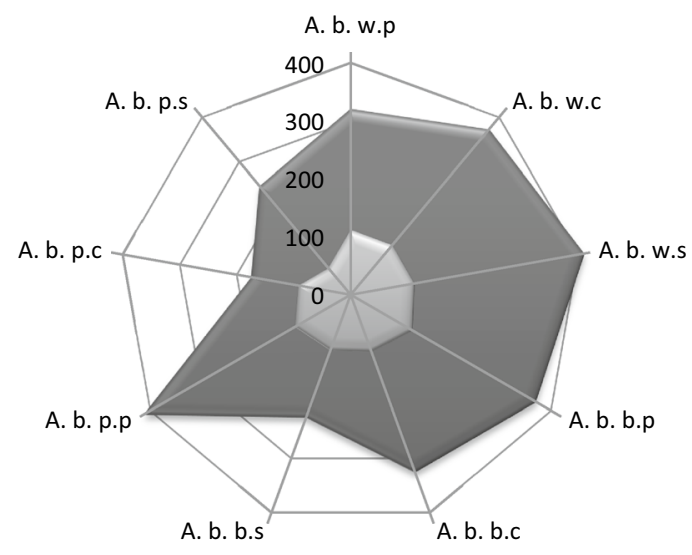

$\square \mathrm{Na}$

$\square \mathrm{Mg}$

Fig. 3 Comparison of the average contents of $\mathrm{Na}$ and $\mathrm{Mg}(\mathrm{mg} / \mathrm{g} \mathrm{dw})$ in the other variety $A$. bisporus (A. b. w A. bisporus white variety, $A$. $b$. $b$ A. bisporus brown variety, A. $b$. $p$ A. bisporus portobello variety, letter $p$ peel of cap, $c$ cap, $s$ stipe)

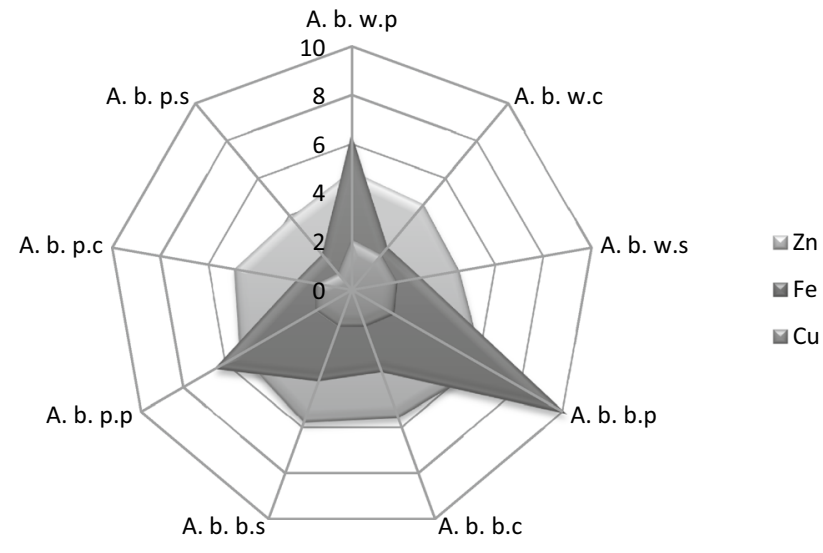

Fig. 4 Comparison of the average contents of $\mathrm{Zn}, \mathrm{Fe}$, and $\mathrm{Cu}(\mathrm{mg} / \mathrm{g}$ $\mathrm{dw}$ ) in the other variety A. bisporus (A. b. w A. bisporus white variety, A. b. $b$ A. bisporus brown variety, A. $b$. $p$ A. bisporus portobello variety, letter $p$ peel of cap, $c$ cap, $s$ stipe)

within the different parts of the same variety for all examined elements and parts of fruiting bodies (except the amount of sodium in the white variety of A. bisporus), that the content of above particular elements in cap peels is the highest. Statistically significant differences were observed in the portobello variety of A. bisporus for the concentrations of zinc and copper, compared to their amounts in the cap peel and stipe (for $\mathrm{Cu}$ and $\mathrm{Zn}$ ), as well as the cap peel and cap (for $\mathrm{Zn}$ ), and between the cap and the stipe in case of $\mathrm{Cu}$ (Table 2). The same relationship for the increase of particular element content in different parts of the fruiting bodies may be noticed for both copper and zinc, that is, the lowest amounts of elements were found in stipes, higher in caps, and the highest in cap peels. The differences, significant according to the applied statistical calculations, were also shown in case of iron content for all the examined varieties of button mushroom within their individual parts. The content of the element in the cap peel of white, brown, and portobello varieties of A. bisporus clearly differs from its content in both stipes and caps, and is the largest, amounting to $6.4 \mathrm{mg} / 100,10.2 \mathrm{mg} / 100,6.5 \mathrm{mg} / 100 \mathrm{~g}$ d.w., respectively.

\section{Organic compounds}

The RP-HPLC method was proven to be effective for the efficient separation as well as qualitative and quantitative analysis of the examined organic compounds, indole and phenolic compounds, in varieties and parts of $A$. bisporus fruiting bodies (cap peels, caps without the peel, and stipes of the fruiting bodies).

\section{Indole compounds}

The compounds from this group were determined in this study due to their important properties involving intrasystemic homeostasis, antioxidant, and even antidepressant activities. L-Tryptophan is sometimes associated with antidepressants used in the treatment of depression. This compound is a component of dietary supplements designed for use in stressful situations or during problems with sleeping. In the human body (in the central nervous system), L-tryptophan is converted into serotonin and melatonin [27]. The highest total content of indole compounds in all A. bisporus varieties was found in the outer part of the mycelium forming the cap, so-called cap peel, and it was in the range of 196-239 $\mathrm{mg} / 100 \mathrm{~g}$ d.w. (Table 2). The highest total content of indole compounds [L-tryptophan, 5-hydroxytryptophan (5-HTP), serotonin, tryptamine, and 5-methyltryptamine] and their highest amounts among $A$. bisporus varieties were found in the brown variety. The fruiting bodies of the white variety revealed the presence of only L-tryptophan and 5-HTP.

The compound present in all varieties and parts of fruiting bodies in the largest quantities was 5-hydroxy-L-tryptophan (from $191.9 \mathrm{mg} / 100 \mathrm{~g}$ d.w. in stipes of the portobello variety to $185.9 \mathrm{mg} / 100 \mathrm{~g}$ d.w. in cap peels of the white variety). 5-HTP is an amino acid naturally occurring in living organisms. It is the direct product of serotonin biosynthesis from L-tryptophan. In some countries, it is used in preparations of antidepressants, to reduce hunger feelings, and as a sedative agent.

Melatonin was only found in the portobello variety at $2.3 \mathrm{mg} / 100 \mathrm{~g}$ d.w. The highest total concentration of indole compounds in all varieties was found in cap peels (196.0 $239.6 \mathrm{mg} / 100 \mathrm{~g}$ d.w.), slightly lower amounts were determined in stipes (129.1-211.0 mg/100 g d.w.), and the lowest in caps without peel (13.4-98.9 mg/100 g d.w.). 
The amounts of determined indole compounds are comparable and do not differ from the amounts obtained in previous studies $[26,28]$. The obtained total contents of indole compounds in the fruiting bodies of A. bisporus prove that they are one of the most valuable sources of those compounds in the diet and can be an alternative for vegetarians, with regard to essential amino acid content (characteristic of mammalian meat).

\section{Phenolic compounds}

The presence of six phenolic compounds, such as gallic acid, protocatechuic acid, $p$-hydroxybenzoic acid, syringic acid, cinnamic acid, and rutin, was determined in all varieties of white mushroom and in all its parts (cap peels, caps without the peel, and stipes of the fruiting bodies). The amounts of the determined phenolic compounds ranged from 0.1 to $11.1 \mathrm{mg} / 100 \mathrm{~g}$ d.w. (Table 2). The highest content of the examined phenolic compounds, as previously described indole compounds, was found in all examined varieties in the outer part of the mycelium forming the cap-the cap peel (16.2$26.5 \mathrm{mg} / 100 \mathrm{~g}$ d.w.). The brown variety was characterized by the highest total content of phenolic compounds, whereas the lowest amount of the content was found in the portobello variety. Among the phenolic compounds found in the examined varieties and parts, rutin was the dominant metabolite (up to $11.1 \mathrm{mg} / 100 \mathrm{~g} \mathrm{~d}$.w.), whereas among phenolic acids, it was gallic acid $(9.2 \mathrm{mg} / 100 \mathrm{~g}$ d.w.), and its highest concentration in each case was observed in the outer part of the mycelium of A. bisporus cap (peel).

Phenolic compounds are widespread antioxidant compounds found in nature, especially in plants and mushroom species. These compounds commonly found in natural raw materials can be divided into two groups: derivatives of hydroxybenzoic acid ( $p$-hydroxybenzoic, protocatechuic, vanillic, syringic, and gallic acid) and derivatives of cinnamic acid ( $p$-coumaric, caffeic, ferulic, and sinapic acid). Hydroxybenzoic acid derivatives are most commonly present in the complexes with lignans, hydrolyzing tannins, or in combination with sugar or an organic acid. In turn, cinnamic acid derivatives are found in nature as esters or are connected via an ester bond to the cell wall structural proteins $[29,30]$. Phenolic acids are valuable antioxidants; they neutralize and prevent free radical formation, inhibit peroxidase activity, and bind with metals intermediating oxidation processes. The strongest antioxidant properties among the phenolic compounds are attributed to the phenolic acids [31]. The contents of phenolic compounds found in the examined material prove that all varieties of A. bisporus are their source for the consumers.

\section{Chemometric analysis}

The research on the metal content supports the thesis that mushrooms (also A. bisporus) accumulate micronutrients. Hence, it seems valuable to obtain information on the existence of correlation between the species of the fungus and the presence of a tendency to accumulate in the metal. An extensive amount of data and the relatively high dispersion of results $(0.9 \mathrm{mg} / \mathrm{g}$ d.w. for $\mathrm{Cu}$ and $412.5 \mathrm{mg} / \mathrm{g}$ d.w. for $\mathrm{Na}$ ) made clear that the interpretation of the data is complicated. Therefore, in order to complement the discussion presented previously and the results, chemometric analyses were used, particularly CA and PCA. These methods are based on a multidimensional approach, as all real processes occurring in nature are a complex phenomenon that can be defined only on the basis of the number of mutually correlated relationships. The task of chemometrics is "gaining" as much information from the obtained measurement data, which often is not visible to the "naked eye" of the analyst.

In the conducted chemometric data analysis, the term "object" corresponds to analyzed samples. Referring to the mushroom A. bisporus, in which the contents of biometals were determined, we can conclude that each sample ( $A$. bisporus white variety, $A$. bisporus brown variety, $A$ bisporus portobello variety), described by $n$-parameters (i.e., the concentration of the analyzed metal), is the point in $m$-dimensional space, and each parameter is the point in $m$-dimensional space of the tested samples. This approach allows for the analysis of similarity within the samples of the parameter space, and likewise a similarity analysis of the parameters in the sample space. In this case, the key is the relationship between the parameters forming the multidimensional arrangement of chemical data, which can be reduced to a size enabling them to be relatively easily visualized [32-35].

\section{Cluster analysis}

In the first step, for the obtained set of analytical data, CA was used. The method allows for classification of objects as similar, in the case where the designated distances between variables in a multidimensional space are small. As a result, the test set of objects may be associated with the so-called clusters-the groups within which objects are characterized by a similar variation [36, 37]. As the squared Euclidean distance was used, the distance between the clusters in accordance with the Ward's method of agglomeration was calculated, which was based on the concept of analysis of variance, the similarity of features (metal concentration), and the object (various A. bisporus varieties). The results were presented graphically as a so-called dendrogram often, colloquially being called a tree (Fig. 5). The $x$-axis corresponds 


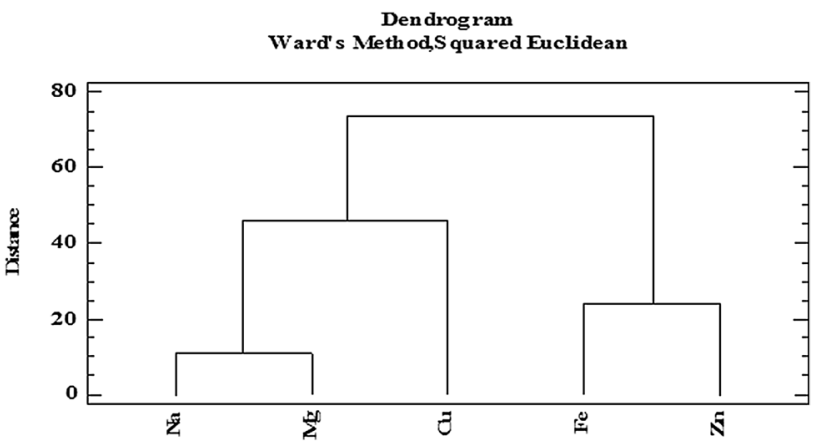

Fig. 5 Dendrogram - similarity of the analyzed elements concentration changes in the other A. bisporus variety (the Euclidean distance square, Ward's algorithm)

to the analyzed elements (Fig. 5) or objects (Fig. 6), and the $y$-axis is the distance between them [36, 37]. Based on our analysis, similarities were observed, the occurrence of the subgroup-clusters within which the objects are similar in characteristics variation (Fig. 5). These parameters correspond to the concentrations of the individual components (metals). In practice, this means that their rate of changes in concentrations is similar, and at the same time, there is a high correlation between them. On this basis, clusters were distinguished. $\mathrm{Na}, \mathrm{Mg}$, and $\mathrm{Cu}$ are within the first cluster, indicating the similarity between their accumulations. In addition, it can be stated that the highest correlation occurs between $\mathrm{Fe}$ and $\mathrm{Zn}$ as evidenced by the shortest length of arms-tree dendrogram. Analyzing dendrograms (Fig. 6) on which the $x$-axis was presented analysed subject can distinguish two distinct focuses. The

Dendrogram

Ward's Method,Squared Euclidean

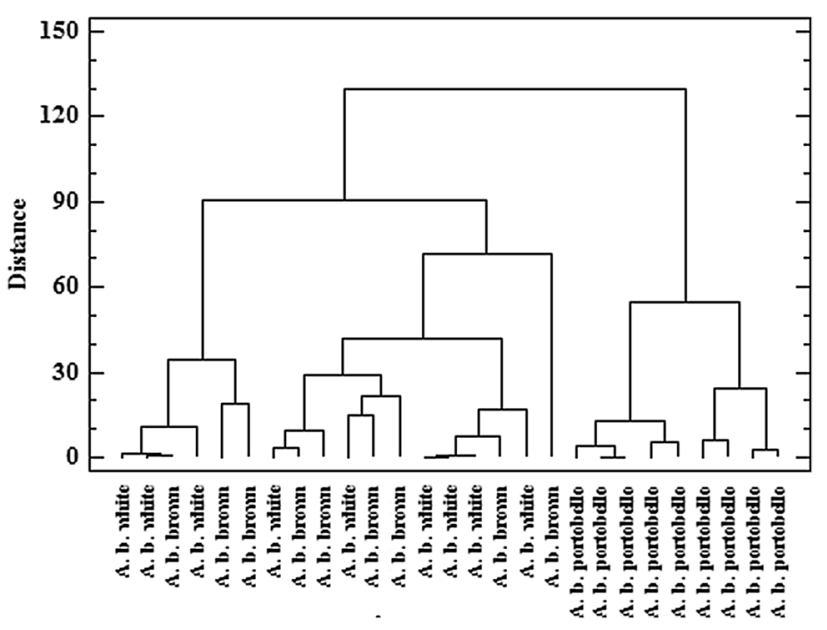

Fig. 6 Dendogram - similarity of the analyzed objects-the samples of other A. bisporus variety (the Euclidean distance square, Ward's algorithm) first cluster (right) on the dendrogram (Fig. 6) corresponds to mushrooms of A. bisporus portobello variety, and the remaining are mushrooms of $A$. bisporus white and brown varieties. This distribution suggests that there is a similar ability to accumulate metals within the white and brown varieties of A. bisporus species, but there is also a highlighted similarity between this group and the portobello variety of the species, as evidenced by the relatively long branches in the dendrogram.

\section{Principal component analysis}

The complementary method used in this work is the PCA. This method can reduce the area of the analyzed variables (measurement data) required to describe the interactions observed between them. With this analysis, it was found that $>85 \%$ of the changes occurring within the test data set is possible to characterize the use of the first three principal components (PC1, PC2, and PC3). As a result of this procedure, it is reasonable to neglect other components during further detailed analysis. The variables (PC1, PC2, and PC3) created in this way correspond to linear combinations of the original variables multiplied by the load assigned to them. The size of the charge corresponds to the level of saturation of a particular variable. This means that this factor is matched to the coefficient of correlation of the primary variables. The decisive influence on the change of the main ingredient is the component that has the largest volume of charge [38, 39]. The resulting amounts of charges of the three main components are presented in Table 3 . Thus, it is concluded that the variables (concentrations of $\mathrm{Mg}$ and $\mathrm{Fe}$ ) had the most significant impact on the size of PC1. Accordingly, in the same manner components PC2 and PC 3 can be associated with the corresponding variables. As a result, this procedure allows the analysis of the results in threedimensional space, which was established on the basis of the three main components. Based on the obtained biplot (a flat three-dimensional space in Fig. 7), it can be seen that the tested objects (A. bisporus portobello variety) form a distinct cluster. Other elements are the white and

Table 3 Factor loads for three first main principal components (PC1, PC2 and PC3)

\begin{tabular}{llcc}
\hline & $\begin{array}{l}\text { Principal compo- } \\
\text { nent 1 }\end{array}$ & $\begin{array}{l}\text { Principal compo- } \\
\text { nent 2 }\end{array}$ & $\begin{array}{l}\text { Principal com- } \\
\text { ponent 3 }\end{array}$ \\
\hline $\mathrm{Na}$ & 0.439 & -0.335 & -0.607 \\
$\mathrm{Mg}$ & 0.531 & -0.085 & -0.288 \\
$\mathrm{Fe}$ & 0.539 & 0.249 & 0.289 \\
$\mathrm{Zn}$ & 0.291 & 0.789 & 0.002 \\
$\mathrm{Cu}$ & 0.387 & -0.443 & 0.681 \\
\hline
\end{tabular}




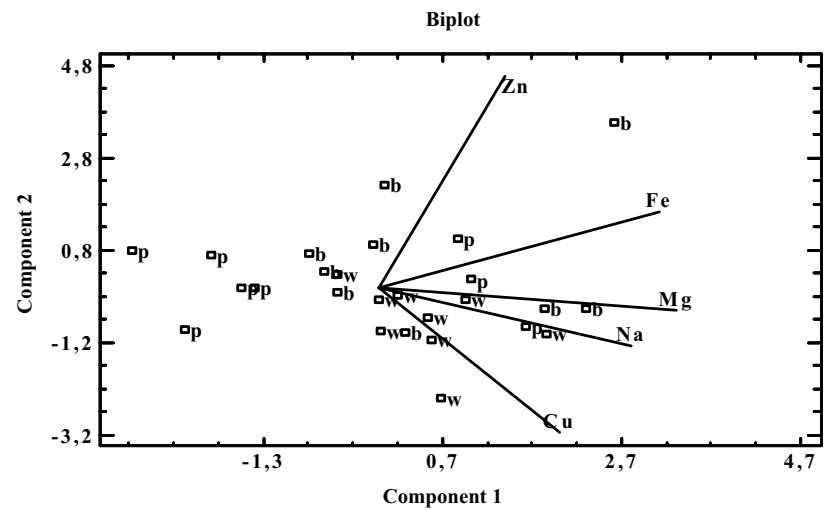

Fig. 7 Biplot graph creates a three-dimensional space presented on plane, shows correlation between the other A. bisporus variety and concentration of macro- and microelements (created on the basis of three main components), w Agaricus bisporus white, $b$ Agaricus bisporus brown, $p$ Agaricus bisporus portobello

brown varieties of $A$. bisporus. Proximity points indicate a significant similarity of the analyzed variables (metal content) within the study groups. The biplot chart (Fig. 7) allows a relatively easy way to track changes at the level of individual elements both within species and between species. Based on the analysis, it was found that the white and brown varieties of $A$. bisporus have a higher bioaccumulation of metals and are richer in metals such as $\mathrm{Mg}, \mathrm{Zn}, \mathrm{Cu}, \mathrm{Fe}$, and $\mathrm{Na}$, in opposition to the portobello variety that exhibits a reduced ability to accumulate these bioelements.

\section{Conclusion}

The differences in the contents of selected bioelements and physiologically active organic compounds in different parts of the three varieties of $A$. bisporus were shown for the first time. The fruiting bodies of all varieties of A. bisporus, especially the brown one, are rich source of bioelements, and indole and phenolic compounds, and their highest quantities are accumulated in the outer part of the fruiting body, that is, the cap peel. Due to the dietary value, removal (peeling) of mushroom cap peel is unjustified, because, as shown, this part of the fruiting body contains the largest amounts of valuable examined components.

Acknowledgements Financial support was from the funds of the Botanical Pharmacy, Faculty of Pharmacy, Jagiellonian University Medical College.

\section{Compliance with ethical standards}

Conflict of interest The authors declare that they have no conflict of interest.
Funding The study was financed from the funds of the Department of Botanical Pharmacy, Faculty of Pharmacy, Jagiellonian University Medical College number: K/ZDS/005619.

Compliance with ethics requirements No ethical approval was required.

Informed consent Not applicable to this study.

Open Access This article is distributed under the terms of the Creative Commons Attribution 4.0 International License (http://creativecommons.org/licenses/by/4.0/), which permits unrestricted use, distribution, and reproduction in any medium, provided you give appropriate credit to the original author(s) and the source, provide a link to the Creative Commons license, and indicate if changes were made.

\section{References}

1. Chang ST (1993) Mushroom biology: the impact on mushroom production and mushroom products. In: Chang ST, Buswell JA, Chiu SW (eds) Mushroom biology and mushroom products. Chinese University Press, Hong Kong

2. Spencer DM (1985) The mushroom-its history and importance. In: Flegg PB, Spencer DM, Wood DA (eds) The biology and technology of the cultivated mushroom. Wiley, New York

3. Cheung PCK (2013) Mini-review on edible mushrooms as source of dietary fiber: preparation and health benefits. Food Sci Human Wellness 2:162-166

4. Koyalamudi SR, Jeong SC, Song CH, Cho KY, Pang G (2009) Vitamin D2 formation and bioavailability from Agaricus bisporus button mushrooms treated with ultraviolet irradiation. J Agric Food Chem 57:3351-3355

5. Labus K, Turek J, Bryjak J (2011) Efficient Agaricus bisporus tyrosinase immobilization on cellulose-based carriers. Biochem Eng J 56:232-240

6. Liu J, Jia L, Kan J, Jin CH (2013) In vitro and in vivo antioxidant activity of ethanolic extract of white button mushroom (Agaricus bisporus). Food Chem Toxicol 51:310-316

7. Muszyńska B, Kała K, Sułkowska-Ziaja K, Gaweł K, Zając M, Opoka W (2015) Determination of indole compounds released from selected edible mushrooms and their biomass to artificial stomach juice. Food Sci Technol 62:27-31

8. Novaes MRCG, Valadares F, Reis MC, Goncalves DR, Menezes MC (2011) The effects of dietary supplementation with Agaricales mushrooms and other medicinal fungi on breast cancer: evidence-based medicine. Clinics 66:2133-2139

9. Roberts J, Teichert A, McHugh TH (2008) Vitamin $\mathrm{D}_{2}$ formation from post-harvest UV-B treatment of mushrooms (Agaricus bisporus) and retention during storage. Food Chem 56:4541-4544

10. Chen YC, Ho K, Hsieh Y, Wang T, Mau J (2012) Contents of lovastatin, $\gamma$-aminobutyric acid and ergothioneine in mushroom fruiting bodies and mycelia. Food Sci Technol 47:274-278

11. Dubost NJ, Ou B, Beelman RB (2007) Quantificaton of polyphenols and ergothioneine in cultivated mushrooms and correlation to total antioxidant capacity. Food Chem 105:727-735

12. Kampmann M, Hoffrichter AC, Stalinski D, Wichmann R (2015) Kinetic characterization of tyrosinase containing mushroom (Agaricus bisporus) cells immobilized in silica alginate. J Mol Catal B-Enzym 116:124-133 
13. Zaidi KU, Ali AS, Ali SA (2014) Purification and characterization of melanogenic enzyme tyrosinase from button mushroom. Enzyme Res. doi:10.1155/2014/120739

14. Shi YL, Benzie IF, Buswell JA (2002) Role of tyrosinase in the genoprotective effect of the edible mushroom, Agaricus bisporus. Life Sci 70:1595-1608

15. Jani AR, Nag S, Setty SR (2016) Visualization of intracellular tyrosinase activity in vitro. Bio Protocol 6:1794

16. Muszyńska B, Kała K, Rojowski J, Grzywacz A, Opoka W (2017) Composition and biological properties of Agaricus bisporus fruiting bodies. Pol J Food Nutr Sci. doi:10.1515/ pjfns-2016-0032

17. Jeong SC, Jeongb YT, Yang BK, Islamb R, Koyyalamudia SR, Panga G, Choa KY, Song CH (2010) White button mushroom (Agaricus bisporus) lowers blood glucose and cholesterol levels in diabetic and hypercholesterolemic rats. Nutr Res 30:49-56

18. Glamočlija J, Stojković D, Nikolić M, Ćirić A, Reis FS, Barros L, Ferreira IC, Soković M (2015) A comparative study on edible mushrooms as functional foods. Food Funct 6:1900-1910

19. Knudsen H, Vesterholt J (2008) Funga Nordica: agaricoid, boletoid and cyphelloid genera. Nordsvamp, Copenhagen

20. Muszyńska B, Sułkowska-Ziaja K, Ekiert H (2011) Indole compounds in fruiting bodies of some edible Basidiomycota species. Food Chem 125:1306-1308

21. Muszyńska B, Sułkowska-Ziaja K, Wójcik A (2013) Levels of physiologically active indole derivatives in the fruiting bodies of some edible mushrooms (Basidiomycota) before and after thermal processing. Mycoscience 54:321-326

22. Ellnain-Wojtaszek M, Zgórka G (1999) High-performance liquid chromatography and thin-layer chromatography of phenolic acids from Ginkgo biloba L. leaves collected within vegetative period. J Liq Chromatogr Relat Technol 22:1459-1471

23. Bernaś E, Jaworska G, Lisiewska Z (2006) Edible mushrooms as a source of valuable nutritive constituents. Acta Sci Pol Technol Aliment 5:5-20

24. Vettel J (2003) Chemical composition of fresh and conserved Agaricus bisporus mushrooms. Eur Food Res Technol 217:10-12

25. Krakowska A, Reczyński W, Muszyńska B (2016) Optimization of the liquid culture medium composition to obtain the mycelium of Agaricus bisporus rich in essential minerals. Biol Trace Elem Res 173(1):231-240

26. Muszyńska B, Smalec A, Sułkowska-Ziaja K, Opoka W, Reczyński W, Baś B (2015) Culinary-medicinal Agaricus bisporus (white button mushroom) and its in vitro cultures as a source of selected biologically-active elements. Int J Food Sci Tech 52:7337-7344

27. Buczko P, Cylwik D, Stokowska W (2005) Metabolizm tryptofanu w ślinie szlakiem kinureninowym. Postepy Hig Med Dosw 59:283-289

28. Muszyńska B, Kała K, Sułkowska-Ziaja K, Krakowska A, Opoka W (2016) Agaricus bisporus and its in vitro culture as a source of indole compounds released into artificial digestive juices. Food Chem 199:509-515

29. Scalbert A, Manach C, Morand C, Rémésy C, Jiménez L (2005) Dietary polyphenols and the prevention of diseases. Crit Rev Food Sci Nutr 45:287-306

30. Vermerris W, Nicholson R (2006) Phenolic compounds and their effects on human health. Phenolic compound biochemistry. Springer, Netherlands

31. Muszyńska B, Sułkowska-Ziaja K, Łojewski M, Opoka W, Zając M, Rojowski J (2013) Edible mushrooms in prophylaxis and treatment of human diseases. Med Inter Rev 101:170-183

32. Gemperline P (2006) Practical guide to chemometrics. Taylor \& Francis, London

33. Johnson R (1984) Elementary statistics, 4th edn. PWN Publishers, Warsaw

34. Miller JN, Miller JC (1999) Statistics and chemometrics for analytical chemistry. Prentice Hall, London

35. Sharaf MA, Illman DL, Kowalski BR (1986) Chemometrics. Wiley, New York

36. Aldenderfer MS, Blashfield RK (1985) Cluster analysis. Sage Publication, Los Angeles

37. Everitt BS, Landau S, Leese M (2001) Cluster analysis. Arnold Publishers, London

38. Guo Q, Wu W, Massart DL, Boucon C, Jong S (2002) Feature selection in principal component analysis of analytical data. Chemometr Intell Lab Syst 61:123-132

39. Wold S, Esbensen K, Geladi P (1987) Principal component analysis. Chemometr Intell Lab Syst 2:37-52 